\title{
A right whale (Mysticeti, Balaenidae) from the Pleistocene of Taiwan
}

\author{
Cheng-Hsiu Tsai ${ }^{1,2^{*}}$ (i) and Chun-Hsiang Chang ${ }^{3}$
}

\begin{abstract}
Current patterns of biological distribution result from the deep past. Of particular interest, some closely related species appear at high latitudes of both hemispheres, but not in between, a pattern known as antitropical distribution. However, the timing, pathway, and drivers of antitropical distributions remain mostly unknown. Here we describe a new fossil, a left tympanic bulla (part of the ear bones), from the Middle/Late Pleistocene (0.78-0.01 mya, but not excluding the possibility of Holocene in age, as the specimen was dredged from the sea bottom and the geological horizon remains uncertain) of Taiwan. The tympanic bulla is diagnostic in baleen whales, and this specimen shows morphological features that are identical to extant Eubalaena, including: relatively large size (the anteroposterior length is $117 \mathrm{~mm}$ ); rectangular outline in medial view; short anterior lobe, judging from the remaining of the lateral furrow; squared anterior margin; prominent transverse crease on the involucrum; transversely compressed in anterior view; well-developed and rounded outer lip; and parallel involucral and main ridges. Although incomplete, the morphological characters and overall similarity to extant Eubalaena allow a reliable taxonomic assignment to Eubalaena sp. The occurrence of a Pleistocene Eubalaena on the southern margin of the western North Pacific is the first balaenid fossil evidence indicative of the biotic interchange between two hemispheres leading to the origin of antitropical distribution in the Pleistocene; alternatively, this specimen might merely represent an extra-limital record of the North Pacific Eubalaena. Furthermore, this find suggests that the Eubalaena interchange, being one of the largest species displaying antitropical distribution pairs in the history of life, likely took place along the western Pacific. Notably, this does not preclude the Eubalaena interchange from other routes, such as the eastern Pacific or the Atlantic Ocean, and future finds should test the scenario for the biotic interchange between Northern and Southern Hemispheres of Eubalaena.
\end{abstract}

Keywords: Cetacea, Eubalaena, Fossil, Biogeography, Antitropical distribution, The Pacific Ocean

\section{Introduction}

Biogeographic patterns are dynamic and constantly evolving. Of various geographical patterns, the antitropical distribution in which closely related species appear at high latitudes of the Northern and Southern Hemispheres, but not in the tropical regions, is singular and remarkable. Recognition of such discontinuous distributions in latitude has been noted since Darwin [1], but the details, including the pathway, timing, and drivers of antitropical distributions remain largely unspecified and speculative $[2,3]$. Glacial and interglacial periods during the Pleistocene have been

\footnotetext{
*Correspondence: whaletsai@ntu.edu.tw; craniata@gmail.com

'Department of Life Science, National Taiwan University, Taipei 10617, Taiwan

${ }^{2}$ Institute of Ecology and Evolutionary Biology, National Taiwan University,

Taipei 10617, Taiwan

Full list of author information is available at the end of the article
}

associated with the origins of antitropicality [2, 3]. Yet, in addition to the lack of Pleistocene fossils to support this hypothetical connection, in fact, some dispersal events crossing the equator that gave rise to the antitropical distributions occurred prior to the Pleistocene $[4,5]$.

Here we describe a new tympanic bulla from the Pleistocene of Taiwan (Fig. 1). The tympanic bulla in Mysticeti (baleen whales) is diagnostic [6-8], and this new specimen matches the unique morphological features of Eubalaena (right whales). Given its geological and geographic occurrence, this Pleistocene Eubalaena lends support to the glaciation/interglaciation hypothesis. Moreover, it implies that the Eubalaena interchange may have taken place between Northern and Southern Hemispheres along the western Pacific (not excluding the possibility of other dispersal routes, such as the eastern Pacific or the

(c) The Author(s). 2019 Open Access This article is distributed under the terms of the Creative Commons Attribution 4.0 International License (http://creativecommons.org/licenses/by/4.0/), which permits unrestricted use, distribution, and 


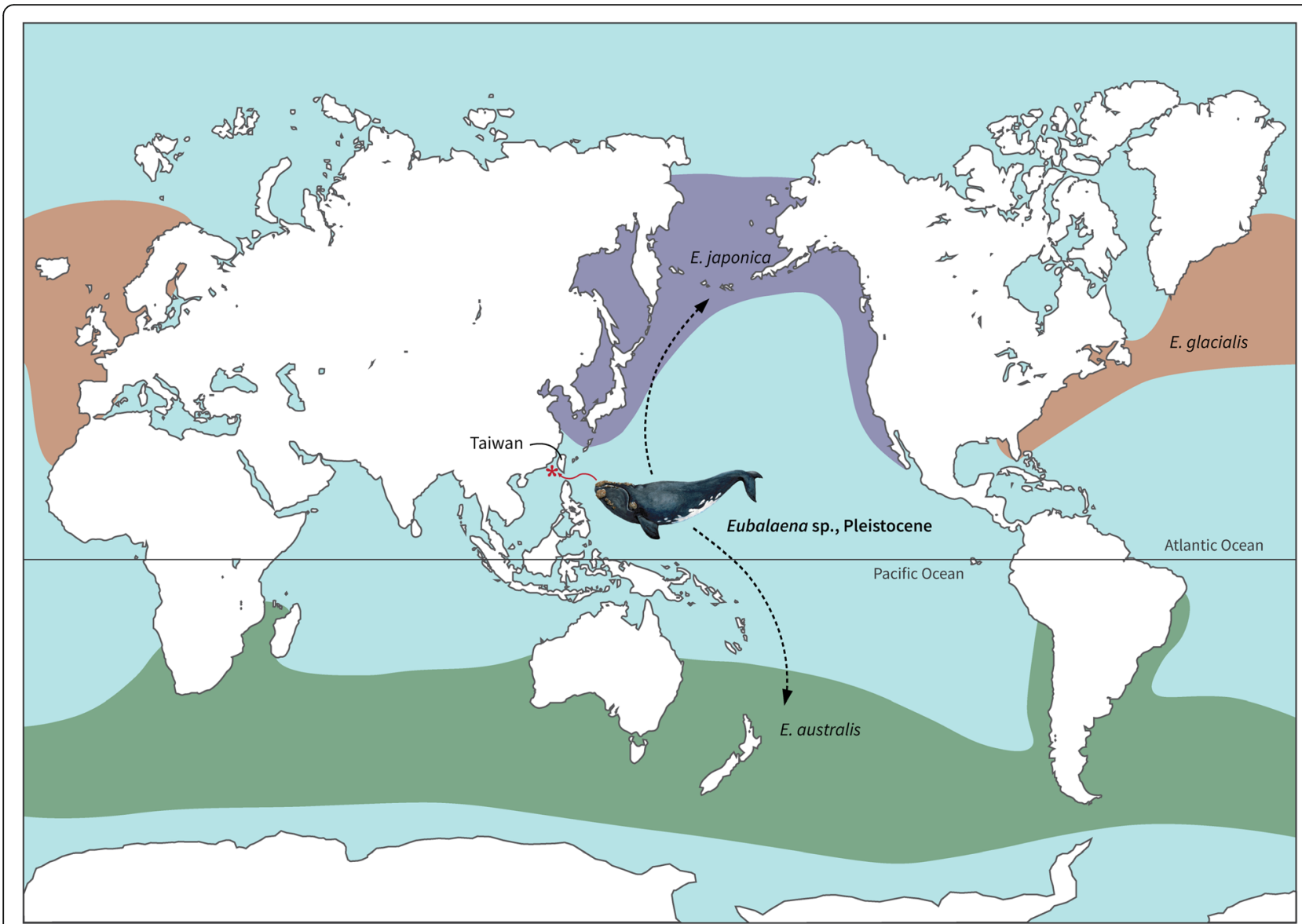

Fig. 1 The occurrence of a tropical Eubalaena from the Pleistocene of Taiwan (starred) and the proposed distribution of Eubalaena australis, E. glacialis, and E. japonica (tinted, modified from Wilson and Mittermeier [28]). The dash line indicates a possible western Pacific pathway for the Eubalaena interchange

Atlantic Ocean). Similarly, this find may support the hypothesis that E. australis (Southern right whale) is more closely related to E. japonica (North Pacific right whale) than E. glacialis (North Atlantic right whale) [9-13]. However, other studies have suggested alternative scenarios for extant Eubalaena relationships [14-16], especially a recent, large-scale genomic research substantiating a northern clade with the Southern right whale being the sister taxon [17] that should warrant more considerations and effort to fully reveal the origin and evolutionary history of the antitropical distribution of Eubalaena.

\section{Materials and methods}

Anatomical terms of the tympanic bulla mainly follow Mead and Fordyce [18], Tsai and Fordyce [19], and Tsai and Boessenecker [7], unless specifically stated. Fossil and extant specimens for morphological comparisons are curated in the following collection.

\section{Institutional abbreviation}

NTUM-VP: Vertebrate Paleontology, Museum of Zoology, National Taiwan University, Taiwan;

\section{Results}

\section{Systematic paleontology}

Cetacea Brisson, 1762.

Mysticeti Gray, 1864.

Balaenidae Gray, 1821.

Eubalaena Gray, 1864.

Eubalaena sp.

\section{Referred specimen}

NTUM-VP 190807 is an isolated and incomplete left tympanic bulla (Fig. 2; Table 1). A high-resolution 3D file is digitally curated at doi.org/10.5281/zenodo.3402015 or https://scholars.lib.ntu.edu.tw/handle/123456789/424590 and can be freely downloaded for detailed examination of the morphology. 


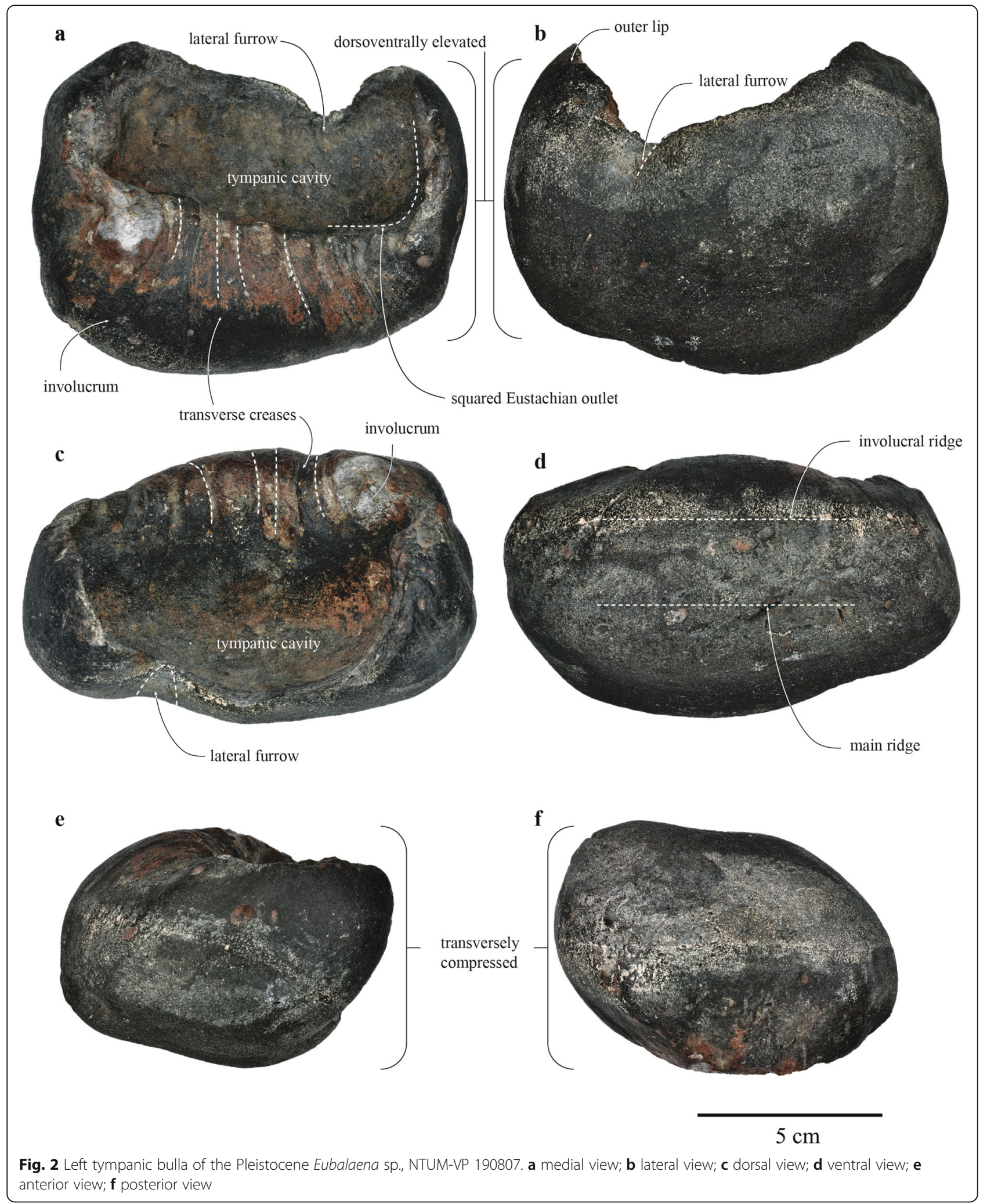

\section{Locality and geological horizon}

Fishermen found the original fossil from the sea bottom during the trawling operations in the Taiwan Strait (widely known as Penghu Channel), and abundant fossils have been recovered over the years. Properly documented fossils from this locality in the paleontological 
Table 1 Measurements (in mm) of the left tympanic bulla of Eubalaena sp., NTUM-VP 190807

\begin{tabular}{lc}
\hline Dimension & Measurement (mm) \\
\hline Maximum length & 117.71 \\
Maximum width in dorsal view & 65.26 \\
Maximum height, & 89.02 \\
Maximum length of the tympanic cavity & 86.15 \\
Height of involucrum, from the base of the anterior point of the inner posterior pedicle to ventral-most point & 56.94 \\
Length of the anterior lobe, from ventral margin of the lateral furrow to anterior-most tip & 36.07 \\
\hline
\end{tabular}

literature are still relatively sparse. However, the faunal composition based on the published fossils includes marine and terrestrial mammals [20-22], reflecting the shallow bed of the Taiwan Strait that converted between sea and land during the interglaciations and glaciations in the Pleistocene. Currently, no evidence is available to identify the precise age of each interglacial marine or glacial terrestrial fossil that was dredged from the Taiwan Strait. Given the disagreement and uncertainty of the geological age among various studies [20-24], for now, this specimen is better to be broadly dated to the Middle to Late Pleistocene (0.78-0.01 mya, but also not excluding the possibility of Holocene in age, as no microfossils were successfully sampled for dating; other attempts, including faunal comparisons and radiometric dating, yielded limited and unclear results) until further research comes to light.

\section{Diagnosis and descriptive remarks}

The dorsal portion of the left tympanic bulla, NTUM-VP 190807 , is broken, leaving the tympanic cavity exposed. Regardless of missing some critical features, such as sigmoid and conical processes, broken lateral furrow, and most of the outer lip, the preserved specimen still exhibits distinct and identifiable characters that allow recognition of its taxonomic affinity to Eubalaena [6], including (Fig. 2)

1. relatively large size - the anteroposterior length is $117 \mathrm{~mm}$ (Table 1);

2. rectangular outline in medial view;

3. short anterior lobe, judging from the remaining of the lateral furrow;

4. dorsally elevated and rounded outer lip on the anterior lobe;

5. squared anterior margin in anterior view;

6. squared Eustachian outlet;

7. prominent transverse creases on the involucrum;

8. transversely compressed in anterior view;

9. parallel involucral and main ridges.

Given the incompleteness of the Taiwan specimen, unresolved morphological differences of earbones (tympanic bulla and periotic) among three extant Eubalaena (E. australis, E. glacialis, and E. japonica), and no tympanic bullae of two additional extinct species of Eubalaena (E. ianitrix [16] and E. shinshuensis [25]), this specimen is currently identified as Eubalaena sp. In addition, the spongy texture and small size of specimen NTUM-VP 190807 (117 mm) in comparison with the range of Eubalaena bullae (112 to $161 \mathrm{~mm}$ [[6]]) suggests that it likely belonged to a relatively young individual, complicating further taxonomic assignment to the species level [26, 27]. However, the unique morphological features of Eubalaena bullae listed above provide a reliable identification at the genus level.

\section{Discussion}

The morphology of NTUM-VP 190807, albeit incomplete, broadly matches that of the genus Eubalaena as described above (Fig. 2). Taxonomy of extant Eubalaena (right whales) remained elusive and inconclusive until Rosenbaum et al. [12] first attempted to build a molecular phylogeny that demonstrated Eubalaena should be differentiated from Balaena at the genus level (an authoritative book on marine mammal taxonomy published in 1998 [28] suggested that Eubalaena as a genus should be disregarded) as well as three distinct Eubalaena lineages. Now, three living species of Eubalaena, including E. australis, E. glacialis, and E. japonica, are widely accepted taxonomically [29, 30], but detailed morphological differences among Eubalaena spp. remain unresolved, as phylogenetic or morphological studies of baleen whales often treated Eubalaena spp. as a single operational taxonomical unit $[6,31,32]$. Baleen whale ear bones prove to be diagnostically and phylogenetically informative $[6,7,19]$. Thus, even only partially preserved, further research on the morphological disparity of the tympanic bulla of extant Eubalaena spp. may show that NTUM-VP 190807 (from the low latitude of the North Pacific) is morphologically closer either to $E$. australis (the Southern right whale) or to E. japonica (the North Pacific right whale), thus likely revealing the direction of dispersal. The discovery of NTUM-VP 190807 as a low-latitudinal occurrence of Eubalaena (Fig. 3, an artistic reconstruction) can be a starting point to decipher the direction and frequency of acquiring the antitropical distribution and should invite further research on the biotic interchange between two hemispheres.

Subtropical or even tropical occurrences of Eubalaena may not seem to be so unusual, because some distribution 


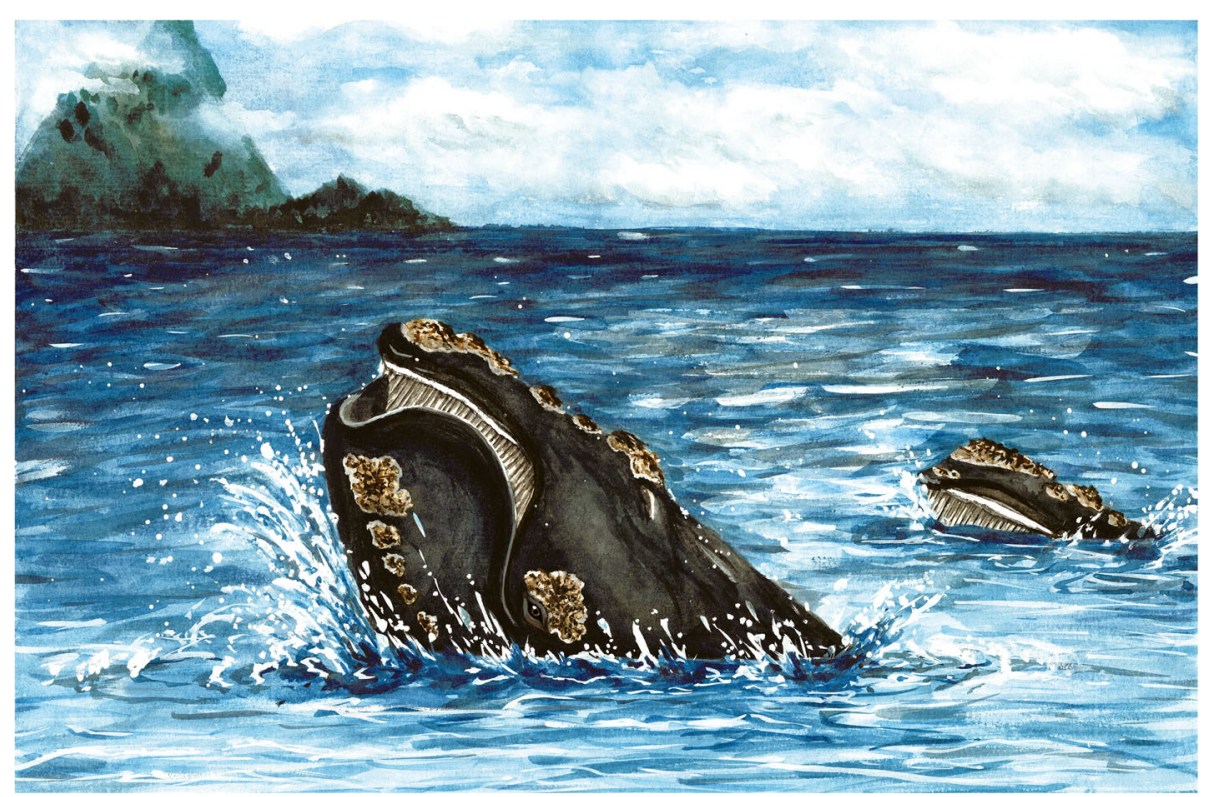

Fig. 3 Artistic reconstruction of tropical Eubalaena in the Pleistocene of Taiwan (@Lab of Evolution and Diversity of Fossil Vertebrates, National Taiwan University; illustrated by Chang-Han Sun)

maps depict the range close to the Equator (Fig. 1, the proposed distribution of extant Eubalaena follows Wilson and Mittermeier [28]). However, three species of extant Eubalaena remain one of the best-known and most widely-cited examples of antitropical species pairs, indicating the preference for inhabiting the temperate waters in the Northern and Southern Hemispheres [29,30]. Judging from the low latitudinal occurrence of Eubalaena represented by NTUM-VP 190807, this tropical balaenid likely existed on the southern margin of the western North Pacific during the glacial period; alternatively, if this specimen was Holocene in age, it might represent an extra-limital record during the interglaciation. The onset of glacial-interglacial shifts since the Pleistocene has long been associated with the antitropicality of marine mammals [2, 33]. In fact, closely related cetacean species (i.e., two distinct species within a genus) that demonstrate antitropical distributions can be found in the Mio/Pliocene (Piscolithax and Messapicetus $[4,34,35]$ ) and perhaps even Oligocene (Yamatocetus, [36]), making the link between the origin of antitropicality and climate oscillations in the Pleistocene not the sole explanation. Similarly, estimates of Eubalaena divergence varies in different studies (e.g., further back to the Pliocene or even Miocene $[11,13,16,32]$ or within the Pleistocene [14, 15]). Thus, NTUM-VP 190807 recovered from the Pleistocene (but see Locality and geological horizon for the age control) of Taiwan represents the first fossil evidence for supporting that the Eubalaena interchange between two hemispheres took place in the Pleistocene, most likely resulting from the glacial and interglacial periods that drove the distribution dynamics.
Nevertheless, alternative interpretations may arise, such as extra-limital distribution, from future research on geological dating or recovery of additional fossils. In addition, the occurrence of NTUM-VP 190807 on the southern margin of the western North Pacific suggests that the western Pacific might be the corridor for the dispersal of Eubalaena when crossing the equator. If the western Pacific pathway indeed leads to the antitropical species pair of Eubalaena, it would, in turn, support the close phylogenetic relationship between northern E. japonica and southern E. australis [9-13], instead of a northern clade or the Atlantic-Southern pair [14-16]. Of note, Eubalaena interchanges between two hemispheres might have crossed the equator multiple times through various routes at different ages that resulted in phylogenetic inconsistency [9-17]; future finds should further reveal more details about the origin and evolutionary history of the antitropical distribution of Eubalaena.

Understanding the turnover of marine megafauna that gave rise to the modern biodiversity is crucial. Knowledge of the megafaunal evolution is not only vital to explaining how the ecological system and its service evolved, as marine megafauna are often nutrient transporters and reservoirs [37], but also to providing insights into the large-scale policymaking for the future, an effort to which conservation paleobiology seeks to contribute [38]. Taken the discovery of NTUM-VP 190807 together with recent finds in this decade, substantial effort has markedly improved our knowledge of marine megafauna in the Pleistocene. For example, Caperea, previously only 
known from the Southern Hemisphere, surprisingly occurred in the Northern Hemisphere as well [39]; Herpetocetus, once thought to exist only prior to the Pleistocene, unexpectedly survived well into the Pleistocene [40]; Eschrichtius, unable to recover its western Pacific population partly due to the unknown breeding site, likely used southern part of the Taiwan Strait for breeding and nursing calves [22]; and two extremely large species, blue and fin whales (Balaenoptera musculus and B. physalus), were first discovered and adequately documented from the Pleistocene [7, 41], further complicating their evolutionary history as $B$. musculus $\times$ physalus pair represents one of the most common hybridizations in marine mammals [42]. As climate change proceeds and unusual occurrences seem to happen more frequently [43-45], more effort into searching Pleistocene sediments, in both overlooked [46] or even well-sampled areas [47], should bring more surprises alive and guide us how to respond to global climate change.

\section{Conclusions}

Discovery of a Pleistocene right whale from the lowlatitudinal region (Taiwan) not only indicates that glacial and interglacial periods in the Pleistocene play a critical role in shaping the biological distribution, but also likely demonstrates that the western North Pacific used to be a corridor of biotic interchanges between two hemispheres. However, the geological dating of specimens from the sea bottom of Taiwan Strait remains poorly resolved, leading to the uncertainties of evolutionary and ecological interpretations; the effort to pin down the ages of various fossils or even Holocene remains should test the hypothesis of Eubalaena interchange presented in this paper. Further research into uncovering more Pleistocene fossils should reveal how biodiversity experienced origination, extinction, survivorship, and dispersal, etc. that leaded to the emergence of modern biodiversity.

\section{Acknowledgements}

We thank the editor, S. Kuratani, for helpful guidance; O. Lambert and an anonymous reviewer for constructive suggestions; I-Lin Lu and his 3D Solutionix company for performing the 3D scan and processing the 3D file; Chang-Han Sun for helping the preparations of Figs. 1 and 2 and illustrating Fig. 3; E. Westwig (American Museum of Natural History, USA), T. Yamada, Y. Tajima, and N. Kohno (National Museum of Nature and Science, Japan), C. Kemper, D. Stemmer, N. Pledge, and M.-A. Binnie (South Australia Museum, Australia) for access to comparative specimens.

\section{Authors' contributions}

Tsai conceived and designed this research; Chang and Tsai collected the data and Tsai analyzed the data; Tsai drafted the manuscript; Chang and Tsai coordinated the study and revised the manuscript. Both authors gave final approval for publication.

\section{Funding}

This research was financially supported by the Taiwan Ministry of Science and Technology (MOST 107-2621-B-002-005 and 108-2621-B-002-006-MY3 to $(H T)$ and public donations to Lab of Evolution and Diversity of Fossil
Vertebrates, National Taiwan University. Funders had no role in study design and preparation of the manuscript.

\section{Availability of data and materials}

The original fossil is curated in the Lab of Evolution and Diversity of Fossil Vertebrates, Museum of Zoology, National Taiwan University. In addition, the 3D data of the actual fossil can be freely downloaded at: doi.org/10.5281/ zenodo.3402015 or https://scholars.lib.ntu.edu.tw/handle/123456789/424590.

Ethics approval and consent to participate

Not applicable.

\section{Consent for publication}

Not applicable.

\section{Competing interests}

No competing interests exist.

\section{Author details}

'Department of Life Science, National Taiwan University, Taipei 10617, Taiwan. ${ }^{2}$ Institute of Ecology and Evolutionary Biology, National Taiwan University, Taipei 10617, Taiwan. ${ }^{3}$ Department of Geology, National Museum of Natural Science, Taichung 40453, Taiwan.

Received: 9 September 2019 Accepted: 12 December 2019

Published online: 28 December 2019

\section{References}

1. Darwin C. On the origin of species: by means of natural selections or the preservation of favoured races in the struggle for life. London, UK: John Murray; 1859

2. Davies J. The antitropical factor in cetacean speciation. Evolution. 1963;17(1): 107-16.

3. Lindberg DR. Marine biotic interchange between the northern and southern hemispheres. Paleobiology. 1991;17(3):308-24.

4. Bianucci G, Collareta A, Post K, Varola A, Lambert O. A new record of Messapicetus from the Pietra Leccese (Late Miocene, Southern Italy): antitropical distribution in a fossil beaked whale (Cetacea, Ziphiidae). Rivista Italiana di Paleontologia e Stratigrafia (Research In Paleontology and Stratigraphy) 2016;122(1):63-74.

5. Churchill M, Boessenecker RW, Clementz MT. Colonization of the southern hemisphere by fur seals and sea lions (Carnivora: Otariidae) revealed by combined evidence phylogenetic and Bayesian biogeographical analysis. Zool J Linnean Soc. 2014;172(1):200-25.

6. Ekdale EG, Berta A, Deméré TA. The comparative osteology of the petrotympanic complex (ear region) of extant baleen whales (Cetacea: Mysticeti). PLoS One. 2011;6(6):e21311.

7. Tsai C-H, Boessenecker RW. The earliest-known fin whale, Balaenoptera physalus, from the Early Pleistocene of Northern California, U.S.A. J Vertebr Paleontol. 2017;37(2):e1306536.

8. Tsai C-H, Fordyce RE. Archaic baleen whale from the Kokoamu Greensand earbones distinguish a new late Oligocene mysticete (Cetacea: Mysticeti) from New Zealand. J R Soc N Z. 2016;46(2):117-38.

9. Churchill $M$, Berta $A$, Deméré TA. The systematics of right whales (Mysticeti: Balaenidae). Marine Mammal Science. 2012;28(3):497-521.

10. Gaines CA, Hare MP, Beck SE, Rosenbaum HC. Nuclear markers confirm taxonomic status and relationships among highly endangered and closely related right whale species. Proc R Soc B Biol Sci. 2005;272(1562):533-42.

11. Kaliszewska ZA, Seger J, Rowntree VJ, Barco SG, Benegas R, Best PB, Brown MW, Brownell RL, Carribero A, Harcourt R et al. Population histories of right whales (Cetacea: Eubalaena) inferred from mitochondrial sequence diversities and divergences of their whale lice (Amphipoda: Cyamus). Mol Ecol. 2005;14(11):3439-56.

12. Rosenbaum HC, Brownell RL, Brown MW, Schaeff C, Portway $V$, White BN, Malik S, Pastene LA, Patenaude NJ, Baker CS et al. World-wide genetic differentiation of Eubalaena: questioning the number of right whale species. Mol Ecol. 2000;9(11):1793-802.

13. Buono MR, Fernández MS, Cozzuol MA, Cuitiño Jl, Fitzgerald EMG. The early Miocene balaenid Morenocetus parvus from Patagonia (Argentina) and the evolution of right whales. PeerJ. 2017;5:e4148. 
14. McGowen MR, Spaulding M, Gatesy J. Divergence date estimation and a comprehensive molecular tree of extant cetaceans. Mol Phylogenet Evol. 2009;53(3):891-906.

15. Steeman ME, Hebsgaard MB, Fordyce RE, Ho SYW, Rabosky DL, Nielsen R, Rahbek C, Glenner H, Sørensen MV, Willerslev E. Radiation of extant cetaceans driven by restructuring of the oceans. Syst Biol. 2009;58(6):573-85.

16. Bisconti M, Lambert $\mathrm{O}$, Bosselaers M. Revision of "Balaena" belgica reveals a new right whale species, the possible ancestry of the northern right whale, Eubalaena glacialis, and the ages of divergence for the living right whale species. PeerJ. 2017;5:e3464.

17. McGowen MR, Tsagkogeorga G, Álvarez-Carretero S, dos Reis M, Struebig M, Deaville R, Jepson PD, Jarman S. Polanowski A et al. Phylogenomic resolution of the cetacean tree of life using target sequence capture. Syst Biol. 2019;syz068.

18. Mead JG, Fordyce RE. The therian skull: a lexicon with emphasis on the odontocetes. Smithsonian Contribution to Zoology. 2009;627:1-248.

19. Tsai C-H, Fordyce RE. A new archaic baleen whale Toipahautea waitaki (early Late Oligocene, New Zealand) and the origins of crown Mysticeti. R Soc Open Sci. 2018;5(4):172453.

20. Chang C-H, Kaifu Y, Takai M, Kono RT, Grün R, Matsu'ura S, Kinsley L, Lin L-K. The first archaic Homo from Taiwan. Nat Commun. 2015:6:6037.

21. Gao J. Penghu fauna. J Mar Sci. 1982;27:123-32.

22. Tsai C-H, Fordyce RE, Chang C-H, Lin L-K. Quaternary fossil gray whales from Taiwan. Paleontological Research. 2014;18(2):82-93.

23. Chang $\mathrm{C}-\mathrm{H}$. The first fossil record of a short-finned pilot whale (Globicephala macrorhynchus) from the Penghu Channel. Bulletin of the National Museum of Natural Science. 1996;8:73-80.

24. Tseng ZJ, Chang C-H. A study of new material of Crocuta crocuta ultima (Carnivora: Hyaenidae) from the Quaternary of Taiwan. Collection and Research. 2007:20:9-19.

25. Kimura T, Narita K, Fujita T, Hasegawa Y. A new species of Eubalaena (Cetacea: Mysticeti: Balaenidae) from the Gonda Formation (latest Mioceneearly Pliocene) of Japan. Bulletin of Gunma Museum of Natural History. 2007;11:15-27.

26. Bisconti M. Morphology and postnatal growth trajectory of rorqual petrosal. Italian Journal of Zoology. 2001;68(2):87-93.

27. Tsai C-H, Fordyce RE. Juvenile morphology in baleen whale phylogeny. Naturwissenschaften. 2014;101(9):765-9.

28. Rice DW. Marine mammals of the world: systematics and distribution. The Society for Marine Mammalogy, Special Publication. 1998

29. Wilson D, Mittermeier R. Handbook of the mammals of the world: volume 4, sea mammals. Barcelona, Spain: Lynx Edicions; 2014

30. Würsig B, Thewissen JGM, Kovacs KM. Encyclopedia of marine mammals, 3rd edn: Academic Press; 2018.

31. Boessenecker RW, Fordyce RE. A new eomysticetid from the Oligocene Kokoamu Greensand of New Zealand and a review of the Eomysticetidae (Mammalia, Cetacea). J Syst Palaeontol. 2017;15(6):429-69.

32. Marx FG, Fordyce RE. Baleen boom and bust: a synthesis of mysticete phylogeny, diversity and disparity. R Soc Open Sci. 2015;2(4):140434.

33. Marx FG, Lambert O, Uhen MD. Cetacean paleobiology: John Wiley \& Sons; 2016

34. Barnes LG. Evolution, taxonomy and antitropical distributions of the porpoises (Phocoenidae, Mammalia). Marine Mammal Science. 1985;1(2): 149-65.

35. Ehret DJ, Macfadden BJ, Jones DS, Devries TJ, Foster DA, Salas-Gismondi R. Origin of the white shark Carcharodon (Lamniformes: Lamnidae) based on recalibration of the upper Neogene Pisco Formation of Peru. Palaeontology. 2012;55(6):1139-53.

36. Boessenecker RW, Fordyce RE. Cosmopolitanism and Miocene survival of Eomysticetidae (Cetacea: Mysticeti) revealed by new fossils from New Zealand. N Z J Geol Geophys. 2017;60(2):145-57.

37. Doughty CE, Roman J, Faurby S, Wolf A, Haque A, Bakker ES, Malhi Y, Dunning JB, Svenning J-C. Global nutrient transport in a world of giants. Proc Natl Acad Sci. 2016;113(4):868-73.

38. Barnosky AD, Hadly EA, Gonzalez P, Head J, Polly PD, Lawing AM, Eronen JT, Ackerly DD, Alex K, Biber E et al. Merging paleobiology with conservation biology to guide the future of terrestrial ecosystems. Science. 2017; 355(6325):eaah4787

39. Tsai C-H, Collareta A, Fitzgerald EMG, Marx FG, Kohno N, Bosselaers M, Insacco G, Reitano A, Catanzariti R, Oishi M, Bianucci G. Northern pygmy right whales highlight Quaternary marine mammal interchange. Curr Biol. 2017;27(19):R1058-9.

40. Boessenecker RW. Pleistocene survival of an archaic dwarf baleen whale (Mysticeti: Cetotheriidae). Naturwissenschaften. 2013;100:365-71.

41. Bianucci G, Marx FG, Collareta A, Di Stefano A, Landini W, Morigi C, Varola A. Rise of the titans: baleen whales became giants earlier than thought. Biol Lett. 2019;15(5):20190175.

42. Bérubé M, Palsbøll PJ. Hybridism. In: Encyclopedia of Marine Mammals. Elsevier; 2018. p. 496-501.

43. Elwen SH, Gridley T. Gray whale (Eschrichtius robustus) sighting in Namibia (SE Atlantic)-first record for Southern Hemisphere. International Whaling Commission document SC/65a/BRG30. 2013:1-5.

44. Scheinin AP, Kerem D, MacLeod CD, Gazo M, Chicote CA, Castellote M. Gray whale (Eschrichtius robustus) in the Mediterranean Sea: anomalous event or early sign of climate-driven distribution change? Mar Biodivers Rec. 2011;4: e28.

45. Tsai C-H, Mead JG. Crossing the equator: a northern occurrence of the pygmy right whale. Zoological Letters. 2018;4:30.

46. Tsai C-H, Fordyce RE, Chang C-H, Lin L-K. A review and status of fossil cetacean research in Taiwan. Taiwan Journal of Biodiversity. 2013;15(2):113-24.

47. Boessenecker RW. A new marine vertebrate assemblage from the Late Neogene Purisima Formation in Central California, part II: pinnipeds and cetaceans. Geodiversitas. 2013;35(4):815-940.

\section{Publisher's Note}

Springer Nature remains neutral with regard to jurisdictional claims in published maps and institutional affiliations.
Ready to submit your research? Choose BMC and benefit from:

- fast, convenient online submission

- thorough peer review by experienced researchers in your field

- rapid publication on acceptance

- support for research data, including large and complex data types

- gold Open Access which fosters wider collaboration and increased citations

- maximum visibility for your research: over $100 \mathrm{M}$ website views per year

At BMC, research is always in progress.

Learn more biomedcentral.com/submissions 